\title{
Squib
}

\section{Typology and Linguistic Areas}

\author{
Mark Donohue
}

\author{
NATIONAL UNIVERSITY OF SINGAPORE
}

\begin{abstract}
A closer look shows that rather than constituting a linguistic area on its own, the region between Lombok and Papua is simply part of a typological continuum that runs from the northern Austronesian languages in Taiwan and the Philippines through Malaysia and western Indonesia east toward Melanesia, without any linguistically definable borders on either side.
\end{abstract}

\section{DEFINING A LINGUISTIC AREA IN "CENTRAL/EASTERN} INDONESIA." In her Rejoinder to Malcolm Ross's squib, Klamer (2003) addresses Ross's critique of her 2002 article, Typical features of Austronesian languages in Central/Eastern Indonesia, stating that, rather than attempting to present a rubric for evaluating genetic relatedness, the article was intended to describe a set of grammatical features that are relevant to the area she discussed (which is "roughly

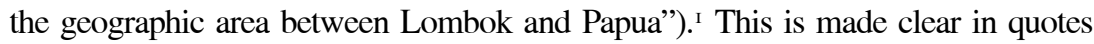
from her discussion such as "regarding the features chosen: how typical are they for the area?," "the paper was intended as a typological characterization of an area," and "complex linguistic areas like C/E Indonesia" [emphases mine].

An approach that addresses areal, rather than historical, issues, does crucially rely on two methodological points that are only addressed in passing: (I) are the morphosyntactic features really typical of the area that Klamer describes, and (2) do these features serve to define this area? Ross (2003:506) suggests not, saying that "the features she enumerates for this region are also widespread among Oceanic languages." While Ross concludes that this commonality confirms "that the major typological divide among Austronesian languages is one that separates the ... languages of Taiwan, the Philippines, Malaysia, western Indonesian, and Madagascar from ... Eastern Nusantara and Oceania," I suggest that there is no "major typological divide" located in the region that Klamer describes, and that the features she examines find as many exemplifying languages to the west of East Nusantara ${ }^{2}$ as they do in the languages to the east of this "area," in as great a proportion of sample set. A qualifying note is required

I. There are some problems with the description of the area. Sasak, spoken on Lombok, is used as an example of a western language, therefore not one from "Central/Eastern Indonesia." This implies that "between Lombok and Papua" should be taken as excluding these named borders. On the other hand, Biak, a language spoken well within Papua, is included.

2. I follow Ross in using this term as more neutral than "Central/Eastern Indonesia," referring as it does to a region containing two countries. 
before proceeding: Klamer states that "the features are 'typical' patterns, quantifying 'typical' as patterns found in more than half of the Austronesian languages in [her] (limited) sample," and explicitly denies that they are "distinctive of the Austronesian languages of $\mathrm{C} / \mathrm{E}$ Indonesia." The first quote gives us a benchmark against which to assess the worth of the features in defining the putative area; the second appears strange, given her title and numerous references inside the original article, but might be taken to indicate that these features are not unique to the "area" she describes. Furthermore, rather than working to define an area, she states that "all but one of the features [the position of a clausal negator-MD] listed here are features of Austronesian languages, ..." (363). This is later qualified, and we are told that there are seven features that are "typical for the C/E Indonesian languages with respect to their Western relatives" (which must refer to the Austronesian languages of the area, because the non-Austronesian languages of East Nusantara have no known western relatives), two that are "areal features of Eastern Indonesia that do not cross genetic boundaries," two that are areal features that do not respect genetic boundaries, and two that "do not define any linguistic area in particular" (377-78). In the following sections I examine these features one by one.

\section{FEATURES "TYPICAL FOR THE C/E INDONESIAN LANGUAGES."}

Here Klamer lists (I) the presence of prenasalized and implosive consonants, (2) preference for CVCV root structure, (3) mental/emotional states being expressed by a $\mathrm{V}+\mathrm{N}$ construction, (4) numerals acting like verbs, (5) no voice system, no case marking, (6) the absence of a passive construction, (7) the generally V-medial clause order, (8) the use of parallelism in discourse, and (9) metathesis as a predominant feature in (morpho)phonology. In this section I address their appropriateness as diagnostics.

I have qualms about these features being characteristic of the languages in the region she describes, and question whether they do indeed set these languages apart from those to the west (or, for that matter, those further to the east). Following a discussion of the morphological and syntactic features that Klamer identifies, I present some data that work toward establishing a linguistic area based in northwest Papua, attested in much of Maluku, and extending into Nusa Tenggara, overlapping with though not with the same scope as the region that Klamer proposes with her listed features.

Prenasalized or implosive stops. Prenasalized stops do seem to be prevalent in the East Nusantara area, but are also found in many languages west of Lombok (e.g., Javanese, Madurese, Rejang); again, a survey in the west is needed before they are used as characteristics of the East Nusantara languages. Foley (I998), cited by Klamer, mentions prenasalization as a typical feature of the Austronesian languages of New Guinea, including areas east of Klamer's region, so clearly this feature is not one that separates the "Central/Eastern Indonesian linguistic area" from areas to the east.

CVCV root structure. The preference for $\mathrm{CVCV}$ roots seems to be a solid one, and one that differentiates the East Nusantara languages from those further west. However, the fact that disyllabic roots are typical of Austronesian languages in general, and that open syllables are the most widely attested syllable types, regardless of language or 
family, weakens this as an area-defining feature: the very typological unmarkedness of CV syllables makes them the natural target for language change, including East Nusantara. This feature could serve as supporting evidence, but is not of itself convincing.

Mental/emotional states being expressed by a $\mathbf{V}+\mathbf{N}$ construction. Klamer herself states that this feature is a characteristic of Malay/Indonesian as well, a language with origins in the far west of the archipelago, but cites a single counter-example (Sasak) to support her notion that it is in fact Malay/Indonesian that is the odd one out. Far from Malay/Indonesian being unusual, numerous grammars of Malaysian and western Indonesian languages attest to the body part + verb constructions that Klamer describes. A short list of representative, but by no means exhaustive, examples includes Malay/Indonesian itself: Saya hati senang (ISG liver content) 'I'm content', Karo Batak Ngena kal atéku kam (love EMPH heart.my you) 'I love you' (Woollams I996:I75), Acehnese brôk akai (bad mind) 'bad-natured, nasty', glah até (untie[d] liver) 'relieved' (Daud and Durie I999:48, 5I), Urak Lawoi' suka hati (like liver) 'happy', susah hati (trouble liver) 'sad', risaw hati (annoyed liver) 'angry', demiq hati (little liver) 'offended' (Hogan I988:I78, I62, I I6), Nias a-fõkhõ tõdõ nia khõ-gu (STAT-sick liver 3SG.GEN DAT-ISG.GEN) 'He is jealous of me' (Laiya I985), Rejang bai' ateui (good liver) 'kind', kidé ateui (bad liver) 'malicious', tjoa adé ateui (not have liver) 'thoughtless', titi' ateui (small liver) 'cowardly' (Jaspan I984). Klamer makes a distinction between $\mathrm{N}+\mathrm{V}$ and $\mathrm{N}+$ Adj collocations, but such a categorial distinction is not always apparent in the languages of the area (see, for instance, Klamer I998:9I: "Kambera does not have a separate category of adjectives"), and so cannot be taken as a defining characteristic. In at least one language of East Nusantara (Tukang Besi), this feature is not well attested (if at all), ${ }^{3}$ which is unusual because the use of such constructions is normal all around the world (compare with English soft-hearted, bighearted, hard-hearted, small-minded, open-minded, level-headed, and Dutch grote hart [big heart] 'generous', German hasen-herzig [hare-hearted] 'timid', gross-herzig [bighearted] 'generous', starr-köpfig [stiff-headed] 'stubborn', Frisch-kunt [cold-bottom] 'person who feels cold' [Kleve dialect], etc.).

Numerals acting like verbs. The verb-like behavior of numerals has been reported in Austronesian languages (and languages of many other families) from outside Klamer's study area: Mosel and Hovdhaugen (I992) report that in Samoan, for example, numerals can only modify a noun if they are in a verbal relative clause, while in Māori (Bauer, Parker, and Evans I993) there is a special modificational construction for numerals if they appear inside an NP, but in both languages the preferential coding for a numeral is as a predicate - that is, in the discourse function that is prototypically occupied by verbs. Both Indonesian and Tagalog have numerals that display properties that are atypical for modifiers, but expected for verbs (such as position in the NP for Tagalog, and preference for predicative, rather than NP-internal modifying, coding

3. The one possible Tukang Besi example I am aware of, ja'o laro / da'o laro (bad inside) 'angry', does not involve a body part (laro shows no semantic extension, metaphorical or otherwise, into the domain of, for instance, ate 'liver', ba'e 'heart', homba 'lung', kompo 'stomach', ho'ou 'gall bladder, spleen', etc.) and does not involve a verb (ja'o / $\underline{d} a^{\prime} o$ is in several places described as an adjective: Donohue I999:9I, 538) (ja'o and $\underline{d} a^{\prime} o$ are dialectal and idiolectal variants of the same lexeme). 
choice for both Tagalog and Indonesian), and unrelated languages such as Koasati (Kimball I99I) and Olo (McGregor and McGregor 1982) also display this parameter. The data are summarized in Donohue (I997a).

\section{No productive voice ('focus") system on verbs; absence of a passive construction.}

Klamer claims that there are no passives and no voice systems in East Nusantara comparable to those in more westerly Austronesian languages, and this, if true, would be a major typological difference between the languages here and those further west, where voice systems are prominent in the syntactic organization of languages. ${ }^{4}$ However, Tukang Besi has a well-described voice system (Donohue I999) that fits well, given its position on the edge of the Western Malayo-Polynesian languages (see Donohue and Maclachlan 2000 for comparison with Kapampangan and Chamorro). Arka (2000, 2002), and Arka and Kosmas (forthcoming) have described the voice systems of a number of languages of Nusa Tenggara, within the region that Klamer discusses, showing that they do display the unmistakable attributes of real voice systems, with passive constructions (similar data are found in Palu'e, from northern Flores), or symmetrical voice systems. In addition to the voice systems attested in these languages, there is strong evidence that a large number of Austronesian languages in a belt stretching at least from Southeast Sulawesi to Southeast New Guinea (such as Larike [Laidig and Laidig I995] and Ambai [Silzer I983]) show a pronominal voice system (Donohue I999: sections 7.6.I, 20.I3), which is also found in languages further east: Misima, Saliba, Tawala, for instance (Callister I987, Mosel I994, Margetts I999, Ezard I997). While Papuan languages are generally described as lacking voice systems, it is in precisely the East Nusantara area that the only published description of a voice system in a Papuan language is to be found (Donohue I996a).

No case on NPs. Klamer declares that a "lack of case marking" (by which she refers to NP-marking) is a feature of East Nusantara, dismissing the case marking in Tukang Besi as "rudimentary." The issues here are threefold: first, whether the Tukang Besi case system can adequately be described as rudimentary; second, whether there is a lack of case marking generally; and third, whether this is a point of contrast with the languages to the west.

The Tukang Besi case system has four members: $n a$, NOM; $t e$, CORE; dili, OBL; and $n u$, GEN. Donohue (I999:5I) states the position on case marking in Tukang Besi clearly: "Any NP referring to a core argument is obligatorily preceded by a core article." Oblique nominals are obligatorily marked by either the oblique case marker, or a more specific preposition (or both), and adnominal modification is marked by the genitive. In short, no NP may appear without case marking - hardly a rudimentary system. Other Muna-Buton languages of Southeast Sulawesi also show case marking: the

4. Klamer uses a definition of "passive" that excludes many of the passive voices of nonwestern Indo-European languages; crucially, it excludes the voice systems found in many Austronesian languages, such as the nonactive voice seen in Indonesian Nasi itu saya masak 'That rice was cooked by me', with a nonoblique agent. I doubt if any Austronesian languages can be unambiguously analyzed as having a passive by the definition she adopts, and because we are comparing different Austronesian languages, these are crucially the languages for which we must tailor a definition. 
$o$ marker is still poorly understood, but interacts with a core argument's syntactic role, discourse prominence, and word order in complex and specific ways, and the oblique case marking system is complex. If we restrict discussion to core arguments, ${ }^{5}$ we find that on the whole the Austronesian languages of East Nusantara do not employ case marking systems - but neither do the non-Austronesian languages of the area. There is a pragmatic-marking system in the languages of north Halmahera (see Wimbish I990), but this is not associated with syntactic information. No general NP-marking is found in the languages of Timor-Alor-Pantar (pronominal distinctions for syntactic role are made in many languages [see (8)-(IO) below], but these are not found as general NP markers). The "no-case marking" parameter is attested in East Nusantara, but where it is found it spans both Austronesian and non-Austronesian language families. The Austronesian languages to the west, however, also widely lack case marking of core arguments (this is attested in numerous descriptions of, for example, Malay, Batak, Javanese, Madurese, Balinese, Acehnese, etc.). The feature cannot be taken as providing support for the notion of East Nusantara as an area distinct from western Indonesia, where the presence of case marking is found only in northern Borneo/Kalimantan and North Sulawesi (with the sole southern exception being Tukang Besi), and in Philippine and Formosan languages north of there. Examining the case systems in those peripheral western Indonesian languages that do possess them, we find that, if anything, the four-member Tukang Besi case system is richer than many languages that adhere more closely to the classical Philippine mould, such as Tagalog (with three distinct cases: ang, NOM; $n g$, GEN; and $s a$, DAT). If these languages, too, are counted as having rudimentary case systems, then the same description must also apply to the whole Austronesian world. Whichever way we examine it, the use of a "no case marking" parameter to characterize East Nusantara Austronesian languages as distinct from either the Austronesian languages to the west or east, or from the non-Austronesian languages in the region, does not work.

Verb-medial rather than verb-initial order. It is undeniable that the bulk of the Austronesian languages of East Nusantara are verb-medial languages; all the evidence we have from Halmahera indicates that, of the non-Austronesian languages that do show a verb-medial order, these languages are the most heavily influenced by Austronesian neighbors, while the less strongly influenced languages are resolutely verb-final. This clearly supports the notion that verb-medialness is a feature of the Austronesian languages of East Nusantara. Missing in this argument, however, is the fact that the languages of Malaysia and western Indonesia are also overwhelmingly verb-medial. Certainly there is documentary evidence that Indonesian, for instance, has developed its present verb-medialness from an earlier state in which it was a verb-initial language (Cumming I99I), but, from a synchronic perspective, the languages can only be described as verb-medial. There are languages in western Indonesia that are not verb-medial, just as there are languages in East Nusantara that are

5. This restriction seems to be justified, because Klamer cites Foley (I998) when she claims that "Papuan NPs, on the other hand, are typically inflected for case"; Foley was discussing case marking systems for core arguments in Papuan languages, and oblique NPs are commonly marked in Austronesian languages throughout west as well as east Indonesia. 
not (such as Tukang Besi). It is, however, true that most of the languages in western Indonesia, as well as East Nusantara, have verb-medial orders, as do the bulk of the Oceanic languages. This feature is not one that distinguishes the East Nusantara Austronesian languages, other than separating Austronesian languages generally from most (but not all-The Bird's Head languages, and the Torricelli family, are notable exceptions) non-Austronesian languages of New Guinea.

Parallelisms. Klamer states that "parallelisms / metathesis are features that do not cross genetic boundaries" (377). Parallelisms have been observed in Kolana, and reported for Buna' (Berthe I972), non-Austronesian languages from Alor and Timor, as well as being amply attested in textual material from languages further east and further west than Klamer's region. In what sense can we say that parallelisms are not found in non-Austronesian languages? They are attested in languages from a range of families in East Nusantara, both Austronesian and non-Austronesian. ${ }^{6}$ Crucially, as Klamer herself states, parallelisms are "typical for a subset of languages in C/E Indonesia that are either geographically adjacent, or linked by a common history, or both" (377). In other words, they neither define nor are typical for the C/E Indonesia area as Klamer delimits it ("between Lombok and Papua") any more than they are a feature that distinguishes Austronesian from non-Austronesian languages.

Metathesis. Metathesis is striking in the Austronesian languages of Nusa Tenggara, being well reported in most documented languages from Timor to Aru, as well as in sporadic reports from outside that area (such as Biak). Similar metathesis can also be observed in the non-Austronesian languages of Alor, such as Kolana, and has also been reported in the verbal morphology of various non-Austronesian languages in southern New Guinea. In passing, we may note that while Klamer states that "[metathesis] does not occur in Muna, Tukang Besi, Taba, Kéo, Bima, Kambera, or Tetun," it is in fact well attested in those languages as a historical process. Examples such as Tukang Besi ho?ou 'gall bladder', a reflex with regular sound changes of PAN *qa(m)peju, via **peqeu (Donohue I999), Cia-Cia tfikolu 'egg', < PAN *qateluR via **tVqeluR (van den Berg I99I), and Palu'e (closely related to Kéo) loke 'skin', < PAN *kulit, are not isolated instances in their respective languages, and illustrate this process quite clearly.

3. AREAL FEATURES OF EASTERN INDONESIA. Two factors are listed as not applying specifically to Austronesian or non-Austronesian languages, but rather being areal features that characterize the East Nusantara area generally: the presence of a morphological distinction between alienable and inalienable nouns, and the presence of clause-final negation. I shall address only the alienable/inalienable distinction here.

6. I have English texts with parallelisms, such as the following from a narration about a failed tree pruning: "a main branch came out, the trunk coming from the tree," "it'd died, y'know, 't'was about to fall", "they tied this rope from the back'a'the ute, up around this, bough, this branch that was coming out." I doubt that we can claim that this is a cross-linguistically marked feature; Klamer mentions that in many languages of East Nusantara "there is generally no stylistic optionality involved in the choice of a proper pair" (370). This, if documented in a variety of languages, would differentiate the East Nusantara verbal performance from that found commonly across the world. 
An alienable/inalienable distinction: an Austronesian feature. An alienable/ inalienable distinction is claimed as another feature of East Nusantara; Blust is cited as claiming that this is a morphosyntactic innovation for languages in the Central MalayoPolynesian, South Halmahera West New Guinea, and Oceanic groups of Austronesian (Central-Eastern Malayo-Polynesian, in short). Klamer claims that this is an East Nusantara trait, and notes "traces of the distinction" in Leti, "statistical tendencies" in Tetun, and "distinct configurations ... but one and the same noun can occur in both constructions" (373) for Buru. She mentions that there is an inalienable/plural marker in Tukang Besi, but there is no different possessive construction: the same morphological marking can be used for any noun.7 Taba is listed as having "lost" the alienable/inalienable distinction: how, from the synchronic perspective that Klamer espouses, is this different from saying that Taba simply does not have such a distinction? Now, given that, of Klamer's set of thirteen "core" languages, she has identified "traces" of an alienable/inalienable distinction in possessive marking in three, it is not convincing to claim that this is a property of East Nusantara. She lists various other languages beyond her core sample as showing an alienable/inalienable distinction, but because there are likely to be (based on the 3/13 hit rate in her core sample) just as many languages in the region that do not show this distinction, we cannot claim that this is a pattern found in more than half of the languages.

Features that "do not define any linguistic area." Again, two features are listed: (I) the generally preverb position of "Agent/Subject" agreement morphology, and the generally postverb position of Object agreement marking, and (2) the post-nominal position of pronominal possessive marking.

Agreement markers are pronominal. Assuming that a language with pronominal agreement markers can be interpreted as a "pronominal argument" language (following, for instance, Jelinek and Demers 1994) is not unproblematic. Bresnan and Mchombo (I987) show that it is quite possible for the status of pronominal indexing in a language to differ according to the different functions it bears. Simpson (I99I) shows that the analysis Jelinek proposes for Warlpiri is not without its problems. In East Nusantara Donohue (I999:I23-29) examines the status of verbal agreement in Tukang Besi, and finds that the P-enclitics can be counted as pronominal, but not the S,Aagreement prefixes. Data on possessive constructions (I999:34I) show that the genitive/possessive clitics can also be considered pronominal in Tukang Besi, but this same stretch of argumentation, contrasting the behavior in Tukang Besi to that of nearby and closely related Muna (van den Berg I989, 2002), shows that in Muna the possessive suffixes cannot be interpreted as being fully pronominal (Donohue I999:34I).

To claim without detailed argumentation that the nominals in the clause are not the syntactic arguments of the verb is unsupported by the observed typological variation within the East Nusantara area. And, of course, it misses the point that a number of languages in this area lack pronominal indexing - Klamer herself refers to Kéo as "almost completely isolating" (372), and Grimes (I99I) makes it clear that Buru functions with-

7. The fact that some possessed nouns can appear in external possessor constructions, while others cannot, seems to define an alienable/inalienable divide, just as it does in English (Donohue 1999b). But this is not the same thing as having a morphologically marked alienable/inalienable distinction. 
out verbal or possessive agreement. (Though there are historical traces of earlier clitics; this begs the question of how much diachronic reconstruction and/or speculation is to be allowed in a typological study: it is unclear how constrained such a study could be, in the absence of a written tradition.) In these languages, the position of nominals cannot be dismissed, and without adequate documentation on a language-by-language basis, claims of fully pronominal status for the bound forms cannot be entertained.

Possessor marked by suffix/enclitic. Klamer claims that suffixal possession is a feature of the Austronesian languages of Central/Eastern Indonesia. As she herself notes (378), the non-Austronesian languages of the region commonly have possessive prefixes (this is attested in both the Timor area languages in the south and in the North Halmahera languages in the north). Among the Austronesian languages there are, however, problems; many languages lack any bound morphology, and some Austronesian languages in this region use prefixal possession. Klamer (372) notes that the languages of southwest Maluku have possessive prefixes; this is more likely to reflect influence from the non-Austronesian languages of the Timor-Alor-Pantar area, which show possessive prefixation, than the geographically distant West Papuan languages that she cites. One such example is Tugun (Hinton I99I), with examples such as u-тити ISG.POSS-machete 'my machete', u-raha (ISG.POSs-house) 'my house', and laso ni-pei (mouse 3SG.POSS-feces) 'mouse's feces' - this last example showing the "reversed genitive" that Brandes (I884) noted for eastern Indonesia. Because marking pronominal possession by suffix or enclitic is common in Austronesian languages wherever they are found, from furthest west to furthest east, it would seem more accurate to talk of the existence of prefixal possession as being a defining feature for the area. Because the suffixal possession feature is not bound to a particular area within Austronesian, but is genetically predictable except in the East Nusantara area, suffixal possession cannot be used to characterize Klamer's area.

\section{Contacts between Austronesian and non-Austronesian speakers date from} approximately $6000 \mathrm{BP}$. The figure of 6,000 years of contact between Austronesian and non-Austronesian speakers in Maluku does not conform with what we know about the dates of Austronesian movements through Southeast Asia to the Pacific. Klamer cites only two sources to support this figure, van Staden (2000) and Andaya (I993). Van Staden offers no references for her claim of 6,000 years of contact history in Maluku; Andaya, who quotes Bellwood (I985) on the subject of prehistoric dates, does not mention a figure of 6,000 years (on page I04 he does mention a date of 2500 BC, citing Bellwood [I985]). ${ }^{8}$ Several sources suggest a much less-than-6,000-year history of Austronesian presence in the area. For example, Bellwood (I985:I23) says that "it is apparent from archaeology that Austronesian settlers had reached Timor by per-

8. In Klamer's Rejoinder she cites Andaya for historical motivation for the assumption that clausefinal negation was originally Papuan. It should be noted that when Andaya refers to "Papuan," he most frequently uses the term to indicate the Austronesian-speaking inhabitants of Biak, Waigeo, and Raja Ampat, in opposition to the (implicitly non-Papuan, in his terminology) Tidore rulers. Clearly Papuan is not used in any linguistic sense, but rather in a phenotypic sense. This, along with his use of "Maluku" to refer to Halmahera and immediate surroundings, needs to be taken into account when assessing his work with respect to linguistic change. 
haps $2000 \mathrm{BC}$," and on page 250 he refers to "Austronesian expansion toward the equatorial zone after 2000 BC." This suggests a much shorter time depth for Austronesians in the Maluku or New Guinea area. Bellwood (I995:IO2) suggests only 3,000 years, though Glover ( I986:204) gives a time of between 5000 and 4000 BP for the inception of widespread economic change in Timor (which might indicate that either the Austronesians had arrived, or that their proximity was being felt).

4. CONCLUSIONS. In sum, Klamer presents between ten and thirteen areal characteristics of the Austronesian languages of Central/Eastern Indonesia (depending on which reading we allow for her position). Of the smaller set of ten features, I have shown that seven are not features that can be used to distinguish the languages in these areas: either they are found in both Austronesian and non-Austronesian languages ("prenasalized and implosive consonants," "roots are generally CVCV," "parallelism," and "metathesis"), or they are found in Malaysia/western Indonesia as much as they are in the more eastern areas ("V+body part noun" constructions, "no case on NPs," "generally V-medial"), or they are simply not characteristic of the languages of East Nusantara ("no productive voice system" / "absence of a passive construction," "morphological distinction between alienable and inalienable nouns"). The remaining features that do characterize East Nusantara (CVCV structure, "numerals acting like verbs," and "clause-final negation") are not strong enough in terms of cross-linguistic markedness, or exclusive enough in terms of not appearing either outside the area or in non-Austronesian languages to define a linguistic area within Austronesian. ${ }^{9}$ Numerous studies of languages of New Guinea show that clause-final negation is a feature that characterizes most of the languages of the entire New Guinea region, not simply the western edge (see Reesink 2002, and the references cited therein).

Table I summarizes the discussion so far. I have used "yes" to indicate that the proposition in that column is true for the feature to the left, and a bracketed "(yes)" to show that this is only a cautious confirmation. Similarly "no" indicates that the feature to the left does not pertain for the proposition above, and "(no)" shows that it probably does not pertain. Thus the presence of CVCV roots is internally well attested in the area in question, shown with a "yes", while the "no case marking" parameter is less well attested, and so is indicated with a "(yes)". The no case marking parameter is not an area-defining feature for East Nusantara, shown as "no", while the presence of an inalienable distinction is only tentatively not a feature of areas east of East Nusantara, and so is shown with "(no)". The bottom row shows the tallies of the "yes" scores: six features are reasonably well attested in East Nusantara, six are found further west, and six are found further east. Clearly, there is not enough evidence to suggest that East Nusantara acts as a linguistic area.

Thus these features taken as a whole do not define a linguistic area "between Lombok and Papua." The only feature that is not shared with the languages either east or west of

9. See Donohue I997a for a discussion of verb-like behavior in numerals, and its cross-linguistic unmarkedness, with special reference to Austronesian languages. References that show verblike behavior for numerals in Austronesian languages not from East Nusantara include Samoan (Mosel and Hovdhaugen I992), Māori (Bauer et al. 1993), and Indonesian (Sneddon I996). This is a common pattern cross-linguistically. 
the region is the areal prevalence for CVCV roots, and, as mentioned earlier, this could be taken as good supporting evidence for a proposed area, but not the main support for the proposition. Alternatively we could take a subset of these typological features and use them to define Klamer's area. To do this, we would need to establish that the properties are sufficiently unusual cross-linguistically to be used as evidence; verb-medialness, for instance, is expected to occur in between one quarter and one third of the languages of the world, and so is not a particularly surprising morphosyntactic feature, and not very good evidence for a linguistic area. Crucially, the constellation of features must occur in each of the languages in the area, not simply a subset of them: if a constellation of features is our criterion, then by examining any given language we must be able to expect to find the constellation (see the methodology espoused in Nichols I996, which Klamer quotes). From the data Klamer presents I do not believe that this is possible.

5. ANOTHER FEATURE. Klamer does not mention what strikes me as a highly salient feature that might define an area in Eastern Indonesia (although not one as extensive as the "Central/Eastern Indonesian" area): the head-marking split-intransitive alignment that is present in the agreement systems of so many of the languages found in the area between Sumbawa and northern Maluku, with a gap about Timor, and a recurrence in central Yapen. ${ }^{\text {o }}$ The following examples from Saweru in central Yapen in Cenderawasih Bay in northern New Guinea introduce this feature (similar data can be found for Yawa in Jones 1986). Here a clause with an agentive intransitive verb such as rayan 'swim' marks its single argument with the same morphology that is used to mark the A of a transitive clause, as can be seen by comparing ( Ia) with (2a). On the other hand, many nonagentive intransitive verbs, such as tesoni 'have diarrhea', mark their sole argument with the same morphology that is used to marked the $\mathrm{P}$ of a transitive verb. This can be seen by comparing ( $\mathrm{Ia})$ and $(2 \mathrm{~b})$.

\section{TABLE 1. KLAMER'S MORPHOSYNTACTIC FEATURES EVALUATED}

$\begin{array}{lllll}\text { FEATURE } & \text { EXTENDS } & \text { INTERNALLY } & \text { EXTENDS } & \text { AREA-DEFINING } \\ & \text { WEST? } & \text { WELL ATTESTED? } & \text { EAST? } & \text { FEATURE? } \\ \text { mb / 6 phonemes } & \text { yes) } & \text { yes } & \text { yes } & \text { no } \\ \text { CVCV roots } & \text { no } & \text { yes } & \text { no } & \text { (yes) } \\ \text { V+N emotional states } & \text { yes } & \text { (yes) } & \text { yes } & \text { no } \\ \text { numerals verbs } & \text { yes } & \text { yes } & \text { no } & \text { no } \\ \text { no voice } & \text { no } & \text { no } & \text { yes } & \text { no } \\ \text { no case marking } & \text { yes } & \text { (yes) } & \text { yes } & \text { no } \\ \text { no passive } & \text { no } & \text { no } & \text { yes } & \text { no } \\ \text { verb-medial } & \text { yes } & \text { yes } & \text { (no) } & \text { no } \\ \text { (in)alienable distinction } & \text { no } & \text { no } & \text { (no) } & \text { no } \\ \text { final negation } & \text { no } & \text { (yes) } & \text { yes } & \text { no } \\ \text { agreement is pronominal } & \text { n/a } & \text { (yes) } & (\text { yes) } & \text { (no) } \\ \text { suffixal possession } & \text { yes } & \text { (yes }) & \text { no } & \text { no } \\ \text { ATTESTATIONs: } & 6 & 6 & 6 & \end{array}$

IO. The areal prominence of this feature was first brought to my attention by C. E. Grimes, whose mentoring I hereby gratefully acknowledge, in a series of talks in I992/I993 (citing works by, among others, Bolton I990, Coward I990, and Hughes I99I). 
TRANSITIVE

(I) a. Mo=na-ba-i.

3SG.F.NOM=2SG.GEN-hit-TNS

'She hit you.'

INTRANSITIVE

(2) a. Mo=rayan-i.

3SG.F.NOM=swim-TNS

'She swam.' b. $\mathrm{No}=\mathbf{r a}-\mathrm{ba}-\mathrm{i}$.

2SG.NOM=3SG.F.GEN-hit-TNS

'You hit her.'

b. Ra-teson-i. 3SG.F.GEN-diarrhea-TNS

'She has diarrhea.'

Particularly striking is the fact that Saweru instantiates a three-way split in intransitive verbs, with a small class of experiential verbs (such as manano 'be lonely') inflecting with dative agreement suffixes, as in (3)a. These same agreement suffixes are used to code low-affect Ps, such as that in (3)b.
(3) a. Manano-inai.
lonely-ISG.DAT
'I'm lonely.'
b. Mo=komi-inai.
3SG.F.NOM=look.for-ISG.DAT
'She looked for me.'

See Donohue (200I) for more details on the morphology of Saweru verbal inflection. The presence of a three-way split is not unusual in the area between Nusa Tenggara and Yapen, as we shall see, and is highly divergent cross-linguistically. This is the kind of highly unusual typological feature that can without hesitation be used to argue for a genetic or areal entity.

While the vast majority of New Guinea languages show nominative-accusative alignment in their agreement marking, the non-Austronesian languages of Halmahera, Yapen, and the (genetically unrelated) Alor and Pantar islands show split-intransitive systems, often with interesting elaborations (e.g., Lamma's highly unusual system in which a nonagentive $S$ is marked the same way as an $A$, and an agentive $S$ is marked the same way as a P, or Tanglapui, in which the inverse system operates in different ways with agentive and nonagentive verbs). Given that split-intransitivity is not a feature of the Austronesian languages of Cenderawasih Bay, nor the non-Austronesian languages of The Bird's Head, this indicates that these regions are not in a pan-genetic area: the presenceof split-intransitive marking in Saweru and its sister Yawa must then be assumed to be a genetic feature of these languages. Their only close relatives are the languages of North Halmahera, and it is these languages that form the edge of the area showing the spread of this parameter across genetic borders.

In Halmahera, a two-way split is attested by Shelden (I99I) for Galela, by Wimbish (I990) for Pagu, and others. The following examples from Pagu illustrate the splitintransitive system in that language. In (4) we can see that the ISG agent is marked by the prefix $t$-, and the human subject prefix $o$-; the same marking is used for the subject in (5)a, but (5)b employs the ISG patient prefix $n$-, along with the 'human object' prefix $i$-.

TRANSITIVE

(4) $\mathrm{Ai}$ ngoak t-o-m-i-olik-oka-ou.

my child ISG.A-SU-3SG.F.P-H-bath-NFUT-PERF

'I've already bathed my daughter.' 
INTRANSITIVE: ACTIVE, STATIVE
(5) a. Ka t-o-tagi.
only ISG.A-SU-go
b. Ngoi n-i-dogoli.
'I've got to go.'
I I I was having labor pains.'

Galela has a similar system. Shelden (I99I:I62) writes that "intransitive [= agentive - MD] verbs take the same prefixes [that] agree with the subject of transitive verbs. Stative verbs take the same prefixes [that] agree with the object of transitive verbs," where stative verbs are "verbs [that] take a subject with a patient-like role," listing "physical states ... experiences ... attributes" as examples of the sorts of predicates that take the $\mathrm{P}$ prefixes to mark their single arguments. Examples illustrating this split can be seen in (8) and (9).

TRANSITIVE

(6) Wo-mi-sasano.

3SG.M.A-3SG.F.P-ask

'(Aweng) questioned her.'

INTRANSITIVE: ACTIVE, STATIVE

(7) a. Wo-mau.

3SG.M.A-want

'He wants (to go).' b. Mi-sirangu.

3SG.F.P-nose.drips

'She has a runny nose.'

Kolana (eastern Alor) achieves a three-way split-intransitive system by having three different absolutive marking options (Donohue I997b). With intransitive verbs we may generalize that the ABS.III prefixes are generally used with experiential verbs, and the ABS.II prefixes with other nonagentive verbs, while the ABS.I prefixes are a default, unmarked, agreement type.

TRANSITIVE

(8)

a. Neta ga-dir.
ISG.ERG 3 3SG.ABS.I-see
'I saw her/him.'

(9) a. Neta gai-tulun. ISG.ERG 3SG.ABS.II-help

'I helped her/him.'

(Io) a. Neta gadi-modo.

ISG.ERG 3SG.ABS.III-discard

'I discarded it.'
INTRANSITIVE

b. Na-miti.

ISG.ABS.I-Sit

'I sat down.'

b. Nai-tain.

ISG.ABS.II-fall.over

'I fell over.'

b. Nadi-mditi.

ISG.ABS.III-sick

'I'm sick.'

The related language Tanglapui (Donohue I996a) shows a split in the intransitives, not by using separate pronominal marking, but by using the inverse marking on verbs with Ps or Ss. In (I I) we can see that when the P of a transitive verb is lower on the animacy hierarchy than the A, there is no special marking. (I2) shows that when the $\mathrm{P}$ is higher in animacy than the $\mathrm{A}$, a verb with an affected $\mathrm{P}$ must mark for inverse, while the verb with a nonaffected $\mathrm{P}$ shows the same coding options as the verb form in ( I Ia) (3SG subjects have no morphological inflection). With intransitive verbs we find a similar split, nonaffected Ss being simply marked on the verb prefixally, while affected Ss require the inverse morpheme, as in (I3b). 
TRANSITIVE: NONAFFECTED AND AFFECTED P

(I I) a. Ya-di-a.

2SG-see-ASP

'You saw (her/him/it),

(I2) a. Di-a.

see-ASP b. Ya-baba.

2SG-hit

'You hit (her/him/it),'

b. Ya-na-baba.

2SG-INV-hit

'(He/It/She) saw (you/her/him/it).' '(He/It/She) hit you.'

INTRANSITIVE: NONAFFECTED AND AFFECTED S
a. Ya-ve.
b. Ya-na-tansi.
2SG-go
2SG-INV-fall
'You went.'
'You fell.'

A split-intransitive alignment is also found in many of the Austronesian languages of the East Nusantara area: it is attested in north Maluku (e.g., Taba [Bowden 200I]), through central Maluku (e.g., Larike [Laidig and Laidig], Nuaulu [Bolton I990]) to the southeast (e.g., Aru [Coward I990, Nivens I992, Hughes 2000]), and, after a gap that includes Timor and much of Flores, numerous other languages in Sumba (e.g., Kambera [Klamer I998]). ${ }^{\text {I }}$ The following examples from Larike (Laidig and Laidig I995) illustrate a similar two-way split from central Maluku.

TRANSITIVE

(I4) a. Ai-tuhe-(y)a.

2SG-break.open-3NHUM

'You broke it open.'

b. Mei-rupu-ne laku eta. 3SG-stab-2SG with needle 'He gave you a shot.'(adapted)

INTRANSITIVE: ACTIVE, STATIVE

a. Ai-nanu.

2SG-Swim

'You are swimming.' b. Pehe-ne.

tired-2SG

'You are tired.'

In Nuaulu (Bolton I990:36-42) from Seram there is a split in which the prefixal agreement is obligatory on all verbs, while the suffixal agreement marker is only used to (optionally) mark the $\mathrm{P}$ of a transitive clause, or (in combination with the prefixes) the $\mathrm{S}$ of a stative intransitive clause. Additionally, the class of intradirective verbs (roughly, motion verbs), those being the class of verbs whose sole argument is simultaneously an agent and also a theme, optionally appear with suffixal as well as prefixal agreement.

I I. We should note that the central and western Flores languages largely lack verbal agreement markers, and so lack the morphology to instantiate a head-marking split-intransitive system. This might explain their absence in this listing. On the other hand, some central Flores languages, at least, (such as Palu'e) show differences between agentive and nonagentive intransitive verbs in terms of the subordinating constructions that are available for them. Similarly, in Buru from west-central Maluku (Grimes I99I:I56-59), another language without verbal agreement in the modern language, we find traces of a split-intransitive system in certain ritual or archaic song lines, even though these morphemes are not productively used in modern spoken language. In ritual leave-taking formulae spoken by some older people, a double-marking pattern in intradirectives is heard: Ka=oli-mo beka? (2SG=return-2SG now) 'Are you going home now?' 


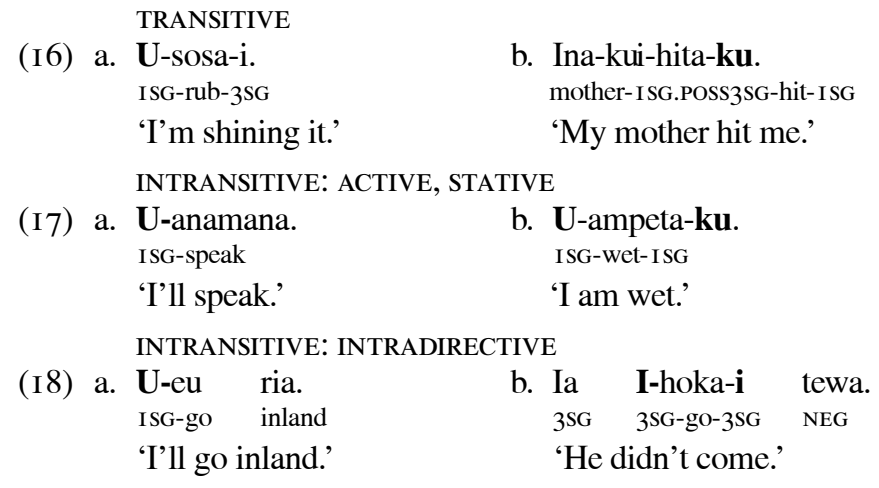

The languages of southeastern Maluku, in Aru and Tanimbar, have a marking system similar to that described above for Nuaulu: the prefixes that mark A are used for agentive Ss, the enclitics that mark $P$ are used for nonagentive Ss (Grimes I992, I993). The examples below come from Dobel of Aru, described in Hughes (I99I), cited in Grimes ( I992); see also Hughes (2000).

TRANSITIVE

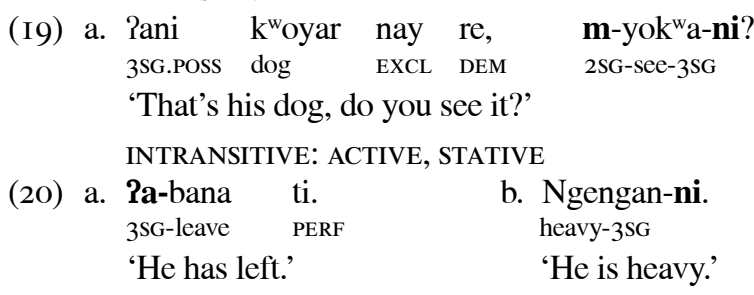

Selaru, from Tanimbar (Coward I990), shows a similar pattern, except that the $\mathrm{P}$ is not indexed on the verb, leaving the verbal enclitics dedicated to nonagentive Ss.

TRANSITIVE

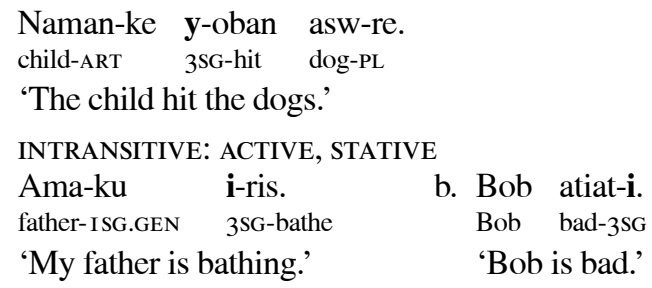

In the southwest, we find that split-intransitivity is found in the Austronesian languages near Alor and Pantar, though not in Flores. Keraf (I978), reporting on the Lamaholot language from the island of Lamalera, notes a similar two-way split-intransitive pattern, with variations. In Lamaholot, the active intransitives optionally take enclitic agreement, but must take agreement prefixes, which are also used to code the $\mathrm{A}$ of a transitive clause. On the other hand, the nonactive intransitives must take enclitic agreement. It is not clear from the source whether or not these enclitics can be used with the $\mathrm{P}$ or a transitive verb, though it is certainly possible for them to be used to show agreement with an A. 
TRANSITIVE

(23) a. Goe k-enu fai.

ISG ISG-drink water

'I drink water.'

INTRANSITIVE: ACTIVE, STATIVE

(24)
a. Goe k-ai(-kã).
ISG ISG-go-ISG
b. Bura-kã.
white-ISG
'I go.'
'I am white.'

Across the Timor/Flores "gap," Kambera (Klamer I998) from Sumba shows a particularly interesting adaptation of this basic system, having adopted a fluid-marking system, rather than the choice of agreement type being purely lexically determined. Of the four simple bound pronominal clitic sets (nominative, genitive, accusative, and dative), an A (transitive subject) may be marked by either nominative or genitive clitics, a $\mathrm{P}$ by accusative or dative clitics, and an intransitive $\mathrm{S}$ is said to be marked by any of these clitics, depending on a complex range of criteria. For instance, Klamer (I998:I73) writes, "an accusative-S construction suggests less active involvement than the canonical meaning of the verb would lead us to expect"; examples of a nominative $\mathrm{S}$ and an accusative $\mathrm{S}$ are shown in (26). Notably, there is also one construction expressing a high degree of evidentiality (Klamer I998:I58-6I) in which the intransitive subject is doubly marked, as in (27).
TRANSITIVE
(25)
a. ... ba ku-yaulu-ha.
when ISG.NOM-chase-3PL.ACC
'... when I chased them.'
b. Na-palu-ka. 3SG.NOM-See-ISG.ACC 'He hit me.' INTRANSITIVE: MORE CONTROLLED, LESS CONTROLLED
(26) a. Ku-hili mai. IPA.NOM-again come 'I'll come again.'
b. ... meti-ya-ka làti. die-3SG.ACC-PRF in.fact '... we would have died.' INTRANSITIVE: HIGH EVIDENTIALITY

$\begin{array}{llllll}\text { I } & \text { Miri } & \text { Yehu na-mài-ya } & \text { la pinu tana. } \\ \text { ART } & \text { Lord } & \text { Jesus } & \text { 3SG.NOM-again-3SG.ACC } & \text { LOC } & \text { top earth }\end{array}$
'The Lord Jesus came down to earth.'

Klamer describes this as a fluid-S system, in which nonlexical factors (one of which is degree of control) influence the choice of marking strategy at least as much as lexical choice.

The areal strength of the split-intransitive system in East Nusantara can be seen in the fact that even Tukang Besi, which has a clear nominative-accusative alignment in its verbal agreement markers (Donohue I996b, I999:I96), shows some elements of this split. Agreement for both agentive and nonagentive Ss is the same, using the prefix also associated with the A of a transitive clause. One construction, however, in which a numeral verb is serialized onto a motion verb, requires double reference to the intradirective $\mathrm{S}$, with a special set of $\mathrm{P}$ clitics in addition to the normal nominative prefixes. 
TRANSITIVE

(28) a. Ko-'ita='e na sa'a.

IPA-see=3P NOM snake

'We saw the snake(s).'

b. No-'ita=kami te sa'a. 3R-SEE=IPA.P CORE snake

'The snake(s) saw us.'

INTRANSITIVE: ACTIVE, STATIVE

(29) a. Ko-wila.

IPA-go

b. Ko-mate.

'We went.'

IPA-die

'We shall die.'

INTRANSITIVE: INTRADIRECTIVE WITH NUMERAL VERB

(30)
a. Ko-mai-gana=kami.
IPA-come-be.four=IPA.P
b. *ko-mai-gana
IPA-come-be.four
'Four of us came.'

The areal nature of this influence is evident in the fact that Tukang Besi, the most southeasterly of the Muna-Buton languages, is the only member of that group to show any evidence of this sort of double marking; clearly Southeast Sulawesi is peripheral to the area I am describing.

Because head-marking split-intransitive systems are not typical of Papuan languages or of Austronesian languages, the concentration of languages with a typologically marked alignment of this kind in a geographically close area can only be taken to represent an areal tendency. This predisposition toward split-intransitivity was probably a Papuan trait initially (though one that crosses genetic lines, appearing both in the possibly Trans New Guinea languages of Timor-Alor-Pantar [Donohue I998] and the West Papuan languages of Halmahera and Yapen Island) that has spread, to differing degrees and in different ways, to the Austronesian languages in the area. We should note that a kind of split-intransitive phenomenon is found in other Austronesian languages, not just those of eastern Indonesia (Foley 2002 presents a topical survey of the kinds of split-intransitivity found in different Austronesian languages, using references mostly from the I980s). Typically, there is a morpheme related to *ma- that marks the less controlled, more stative predicates (see Evans and Ross [200I] for some recent discussion), though this morpheme cannot be thought of as an agreement marker. The kind of split-intransitive phenomenon that involves head-marking with pronominal agreement markers, however, is less widely attested (though Acehnese is an obvious example of a noneastern Indonesian language with such a system [Durie I985, 1987]), but this existing predisposition to differentiate semantically different intransitive predicates might have led to the easier adoption of the head-marking split-intransitive system in East Nusantara.

We can conclude that there is a linguistic area of some description in East Nusantara, but not for the reasons that Klamer puts forward, and not with the geographical spread that she describes. It is predominantly influenced and defined by morphosyntactic features that most likely predate the arrival of Austronesians in the region. Because of the previous approximately three thousand years of contact between speakers of Austronesian and non-Austronesian languages in the area, many of the morphosyntactic traits of western Indonesia have spread to varying degrees in this region. Similarly, many of the morphosyntactic traits of mainland New Guinea have probably 
diffused westward, just as they have infused many of the Oceanic languages whose ancestors passed that way heading east. But there is no evidence that these traits define Central/Eastern Indonesia as an area with a spread "between Lombok and Papua." Furthermore this larger area is not as strongly separated, in terms of typology, from "the west" as Klamer suggests (or, for that matter, from "the east," as Ross points out). Rather, the region between Lombok and Papua is simply part of a typological continuum that runs from the northern Austronesian languages in Taiwan and the Philippines through Malaysia and western Indonesia east toward Melanesia.

\section{REFERENCES}

Andaya, Leonard Y. 1993. The world of Maluku: Eastern Indonesia in the early modern period. Honolulu: University of Hawai' $i$ Press.

Arka, I Wayan. 2000. Voice and being core: Evidence from (Eastern) Indonesian Languages. Paper presented at the AFLA 7 Conference, Amsterdam, May.

- 2002. Voice systems in the Austronesian languages of Nusantara: Typology, symmetricality and undergoer orientation. Paper presented at The Tenth National Congress of the Indonesian Linguistic Society, Bali, July.

- Forthcoming. Passive without passive morphology? Evidence from Manggarai. In Voice in western Austronesian languages, ed. by I Wayan Arka and Malcolm Ross. Canberra: Pacific Linguistics.

Bauer, Winifred, with William Parker and Te Kareongawai Evans. I993. Maori. Descriptive Grammars. London: Routledge.

Bellwood, Peter S. 1985. Prehistory of the Indo-Malaysian archipelago. Sydney: Academic Press.

—. I995. Austronesian prehistory in Southeast Asia: Homeland, expansion and transformation. In The Austronesians: Historical and comparative perspectives, ed. by Peter Bellwood, James J. Fox, and Darrell Tryon, 96-I I I. Canberra: Research School of Pacific and Asian Studies, Australian National University.

Berthe, Louis. 1972. Bei gua: Itinéraire des ancêtres: Mythes des Bunaq de Timor; texte Bunaq recueilli à Timor auprès de Bere Loeq, Luan Tes, Asa Bauq, et Asa Beleq. Paris: Éditions du Centre National de la Recherche Scientifique.

Bolton, Rosemary. I990. A preliminary description of Nuaulu phonology and grammar. MA thesis, University of Texas at Arlington.

Bowden, John. 200I. Taba: Description of a South Halmahera language. Canberra: Pacific Linguistics.

Brandes, Jan Laurens Andries. I884. Bijdragen tot de Vergelijkende Klankleer der Westersche afdeeling van de Maleis-Polynesische taalfamilie. P. W. van de Weijer.

Callister, William. I987 [1985]. How Austronesian focus works in the Misima language. Language and Linguistics in Melanesia I6 ( I-2):7 I-99.

Coward, David F. I990. An introduction to the grammar of Selaru. MA thesis, University of Texas at Arlington.

Cumming, Susanna. I99I. Functional change: The case of Malay constituent order. Berlin: Mouton de Gruyter.

Donohue, Mark. I996a. Inverse in Tanglapui. Language and Linguistics in Melanesia 27 (2): IOI-I 8.

- I996b. Split-intransitivity in Tukang Besi. Oceanic Linguistics 35:294-305.

. I 997a. What are numerals anyway? Paper presented at the Manchester NP workshop, April 26. Handout available online at http://www.donohue.cc, following links to academic, presentations, I997. 
I997b. Developments of affectedness marking in the languages of Alor. Talk, University of California at Berkeley. Berkeley, California, September 25. Handout available online at http://www.donohue.cc, following links to academic, presentations, I997.

- I998. Subgrouping in the languages of Alor and Pantar. Ms, Department of Linguistics, University of Sydney.

- I999. A grammar of Tukang Besi. Grammar Library Series No. 20. Berlin: Mouton de Gruyter.

. 200 I. Split intransitivity and Saweru. Oceanic Linguistics 40:32 I-36.

Donohue, Mark, and Anna Maclachlan. 2000. What agreement in Chamorro? In The Proceedings of the Austronesian Formal Linguistics Association VI, ed. by Carolyn Smallwood and Catherine Kitto, I I-32. Toronto Working Papers in Linguistics. Toronto: University of Toronto, Dept. of Linguistics.

Durie, Mark. I985. A Grammar of Acehnese on the basis of a dialect of North Aceh. KITLV I I 2. Dordrecht: Foris.

- I987. Grammatical relations in Acehnese. Studies in Languages I I (2):365-99.

Evans, Bethwyn, and Malcolm Ross. 200I. The history of Proto-Oceanic *ma. Oceanic Linguistics 40:269-90.

Ezard, Bryan. I997. A grammar of Tawala, an Austronesian language of the Milne Bay area, Papua New Guinea. Series C-I37. Canberra: Pacific Linguistics.

Foley, William A. I998. Toward understanding Papuan languages. In Perspectives on the Bird's Head of Irian Jaya, Indonesia, ed. by Jelle Miedema, Cecilia Odé, and Rien A. C. Dam, 503-I8. Amsterdam: Rodopi BV.

. 2002. Semantic parameters and the unaccusative split in the Austronesian language family. Paper presented at the annual meeting of the Australian Linguistic Society.

Glover, Ian. I986. Archaeology in Eastern Timor. Terra Australis I I. Canberra: Department of Prehistory, Research School of Pacific Studies.

Grimes, Charles E. I99I. The Buru language of eastern Indonesia. PhD thesis, Australian National University.

- I992. Role and reference tracking systems in Central Malayo-Polynesian languages. Seminar, Australian National University, May 22.

- I993. Survey of pronominal systems in languages of Sulawesi, Nusa Tenggara, and Maluku. Seminar, East Indonesia discussion group, Australian National University, June 8.

Hinton, Bryan Douglas. I99I. Aspects of Tugun phonology and syntax. MA thesis, University of Texas at Arlington.

Hughes, Jock. I99I. Dobel, a language of the Aru islands. Ms, Pattimura University and Summer Institute of Linguistics.

- 2000. The morphology of Dobel, Aru, with special reference to reduplication. In Spices from the East: Papers in languages of eastern Indonesia, ed. by Charles E. Grimes, I3 I-80. Canberra: Pacific Linguistics.

Jelinek, Eloise, and Richard A. Demers. I994. Predicates and pronominal arguments in Straits Salish. Language 70:697-736.

Jones, Linda K. I986. The question of ergativity in Yawa, a Papuan language. Australian Journal of Linguistics 6:37-55.

Keraf, Gregorius. I978. Morfologi dialek Lamalera. $\mathrm{PhD}$ thesis, Universitas Indonesia. Ende: Arnoldus.

Kimball, Geoffrey D. I99I. Koasati grammar. Lincoln, Nebr.: University of Nebraska Press.

Klamer, Marian. I998. A grammar of Kambera. Grammar Library Series No. I8. Berlin: Mouton de Gruyter.

Laidig, Wyn, and Carol Laidig. I995. A synopsis of Larike phonology and syntax. NUSA 38:19-42. 
Laiya, Sitasi Z. 1985. Kamus Nias-Indonesia. Jakarta: Pusat Pembinaan dan Pengembangan Bahasa, Departemen Pendidikan dan Kebudayaan.

Margetts, Anna. 1999. Valence and transitivity in Saliba: An Oceanic language of Papua New Guinea. Max Planck Institute Series in Psycholinguistics I2. Nijmegen: Ponsen \& Looijen BV.

McGregor, Donald E., and Aileen R. F. McGregor. 1982. Olo language materials. Series D-42. Canberra: Pacific Linguistics.

Mosel, Ulrike. I994. Saliba. Munich: Lincom Europa.

Mosel, Ulrike, and Even Hovdhaugen. I992. Samoan reference grammar. Oslo: The Institute for Comparative Research in Human Culture.

Nichols, Johanna. I996. The comparative method as heuristic. In The comparative method reviewed: Regularity and irregularity in language change, ed. by Mark Durie and Malcolm Ross, 39-7I. New York: Oxford University Press.

Nivens, Richard. I992. An overview of the languages of the Aru Islands in Eastern Indonesia. Seminar, University of Hawai 'i.

Reesink, Ger P. 2002. Clause-final negation: Structure and interpretation. Functions of Language 9(2):239-68.

Ross, Malcolm. 2003. Typology and language families: A comment on Klamer's "Typical features of Austronesian languages of Central/Eastern Indonesia." Oceanic Linguistics 42:506-IO.

Shelden, Howard. I99I. Galela pronominal verb prefixes. In Papers in Papuan Linguistics, No. I, I6I-75. Series A-73. Canberra: Pacific Linguistics.

Silzer, Peter James. I983. Ambai: An Austronesian language of Irian Jaya, Indonesia. $\mathrm{PhD}$ thesis, Australian National University.

Sneddon, James Neil. I996. Indonesian: A comprehensive grammar. London: Routledge.

van Staden, Miriam. 2000. Tidore: A linguistic description of a language of the North Moluccas. PhD dissertation, Leiden University.

van den Berg, René. I989. A grammar of the Muna language. KITLV, Verhandelingen I39. Dordrecht: Foris.

- I99I. Preliminary notes on the Cia-Cia language (South Buton). In Excursies in Celebes: Een bundel bijdragen bij het afscheid van J. Noorduyn als directeur-secretaris van het KITLV, ed. by Harry A. Poeze and Pim Schoorl, 305-24. Leiden: KITLV Uitgeverij.

- 2002. The place of Tukang Besi and the Muna-Buton languages. Paper presented at the Ninth International Conference on Austronesian Linguistics. Canberra, Australia. January I I.

Woollams, Geoff. 1996. A grammar of Karo Batak. Series C-ı30. Canberra: Pacific Linguistics. 